\title{
Ants inhabiting stumps on clearcuts in managed forest in western Poland
}

\author{
Tomasz Wlodarczyk, Michał Żmihorski \& Anna Olczyk
}

Włodarczyk, T., Żmihorski, M. \& Olczyk, A. 2009: Ants inhabiting stumps on clearcuts in managed forest in western Poland. - Entomol. Fennica 20: 121128.

We studied ant communities living in stumps left on clearcuts. The clearcuts were located in a managed forest in western Poland. Depending on the study site, 10 $80 \%$ of the stumps were inhabited by ant colonies. Lasius platythorax was the dominant of the community. We found the diameter of the stump to be positively related with the occurrence of some ant species. In general, oak and pine stumps were inhabited in a similar proportion. Formica fusca, however, showed a distinct preference for oaks. All species avoided each other with exception of $F$. fusca which preferred all species other than L. platythorax. We did not find the presence of red wood ants to significantly affect the occurrence of ant colonies in these stumps. The results of our investigations indicate that stumps left on clearcuts are convenient nest site for ants. Leaving stumps affects positively the growth of the L. platythorax population.

T. Włodarczyk, Department of Invertebrate Zoology, University of Biatystok, Świerkowa 20 B, 15-950 Białystok, Poland, tel. 4885 745-73-20; e-mail: t.wlodarczyk@uwb.edu.pl

M. Żmihorski, Museum and Institute of Zoology, Polish Academy of Sciences, Wilcza 64,00-679 Warsaw, Poland, e-mail: zmihorski@miiz.waw.pl

A. Olczyk, Students Club of Field Biology, Warsaw University, Banacha 2, 02097 Warsaw, Poland, e-mail: zoltanka@poczta.onet.pl

Received 2 February 2008, accepted 8 September 2008

\section{Introduction}

When studying ant colonization, one can distinguish some rules. Like in plants, the changes in the ant community are directional, so we can call this phenomenon succession. First, the environment is settled by pioneer species. In the case of sandy areas it is the Lasius psammophilus (Gallé 1991; formerly identified as Lasius alienus, Czechowski et al. 2005). During the initial stages of succession of moist pine forests planted on clearcuts, the dominants are L. platythorax and
Tetramorium caespitum (Czechowski et al. 1995, Czechowski \& Czechowska 2006). At places where the forest was cut down, the succession of ants is partially influenced by the forest-dwelling species which survived anthropogenic disturbance i.e. clear-cutting forest and planting young trees. According to former investigations conducted in Polish pine forests, the size of the Myrmica ruginodis population may grow after clearcutting (Mazur 1983, Czechowski et al. 1995). Similar results were obtained for $M$. ruginodis and Camponotus herculeanus living in 
pine and spruce forests in southern Finland, (Punttila et al. 1991, 1996). The course of succession and distribution of ant nests are strongly dependent on interactions between species with the exception of the initial stage (Galle 1990).

In our work we intended to study initial stages of succession of ant community using easy in quantitative comparisons method of examination of tree stumps. At the same time we wanted to see how much the tree stumps are attractive for ants and to compare species in respect of their tendency to use stumps as a nest site. We also aimed to explain the patterns of occurrence of ant nests in tree stumps on the basis of interspecific relations among species.

\section{Material and methods}

The investigations were carried out in northwestern Poland, in the Cedyński Landscape Park $\left(52^{\circ} 48^{\prime} \mathrm{N} ; 4^{\circ} 20^{\prime} \mathrm{E}\right)$. This area is situated within three regions: the Freienwald Basin, the Gorzowska Plain and the Myśliborkie Lake District (Kondracki 2002). The landscape is characterized by sandy hills of glacial origin bordered by flats and situated in the low altitude of the Odra's Valley (Friedrich 1998). The climate of this region is exceptionally mild because of strong oceanic influences. These influences shorten snow cover duration and lengthen the growing season (Friedrich 1998, Falarz 2004).

The analysis of myrmecofauna was conducted in the Mieszkowickie Forest (ca $140 \mathrm{~km}^{2}$ in size). The main type of habitat in this area is the acidophilus oak forest (Kujawa-Pawlaczyk \& Pawlaczyk 1999, own data). The tree stand consists of pine (Pinus sylvestris) and oak, with considerably smaller proportion of the latter. The forest is managed for wood production. Clearcutting is used, so that within tight treestands, open areas are present. New stands regrow as a result of man-made afforestation.

The ants were investigated on eight clearcuts, 0.5 to 7.5 years old. They all were identical in respect to soil type and very similar in tree stand composition (dominance of pines and the presence of oaks). The forests before they were cut down were also similar (90-110 yrs). Three youngest clearcuts $(0.5,1.5$ and 2 yrs $)$ were still before planting. The older ones were planted with pine, with several deciduous species added (oak, birch, Norway maple). Over the course of time, plant cover has increased as a result of colonization of species characteristic for clearcuts such as Calamagrostis sp., Senecio sp.

Each site mentioned above was checked in May or June 2006 for the presence of ants in 46 to 95 randomly selected stumps of two types (pine and oak - we gave up distinguishing common oak and sessile oak). Stumps which were covered with soil, seriously damaged by animals, or partly pulled out from soil as a result of timber harvesting, were rejected for use in our study. Each stump was carefully investigated to find ant colonies. After a short observation of holes and crevices under the bark for potential ant's activity, the stump was knocked with an axe to try to bring ants to the surface. If still no ants appeared, pieces of bark were removed and excavation around the stump took place. If an ant nest was found, examination was continued to see if there were colonies of other species on the same stump. We regarded those stumps as inhabited by ants which served as shelter for brood and/or for workers gathered in tunnels. Stumps inhabited by colonies of Leptothorax ants were neglected in the statistical comparisons. This is because of small numbers of workers in the colonies and because they are so small-bodied (about $2 \mathrm{~mm}$ in length) so they could be easily overlooked, thus giving us false negative observations. The data was classified in a binary way (presence or absence of a colony). Stumps that were only penetrated by a few scattered workers were classified as ant-free. The presence of red wood ants in the neighborhood was determined, as well, on 306 randomly selected stumps in different clearcuts. If at least 3-4 individuals were found within a radius of $0.5 \mathrm{~m}$, the stump was considered as lying in the red wood ants' territory.

Determination of the species status of Lasius niger and L. platythorax was impossible in the field. This is why we took samples from randomly selected colonies to identify them in the laboratory. As a result ants from 52 colonies were collected. All of them were L. platythorax and therefore we made an assumption that the rest of the colonies were also of this species. Formica fusca, Tetramorium caespitum and Formica 


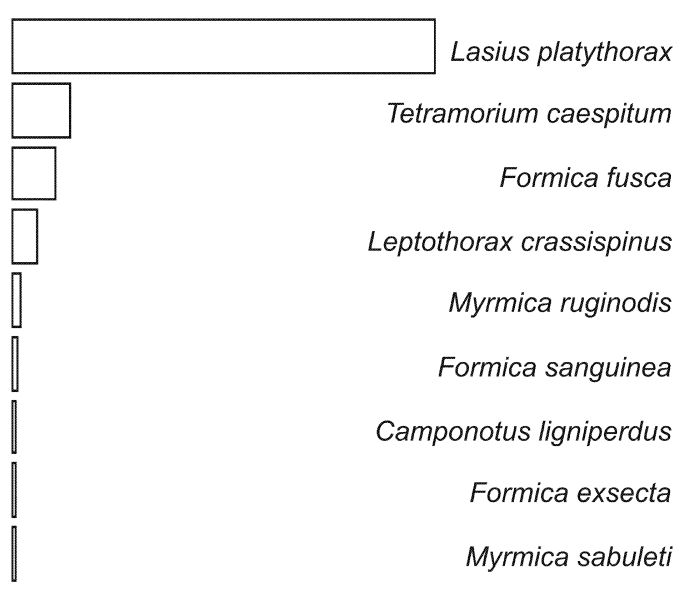

$\begin{array}{llllllll}0 & 25 & 50 & 75 & 100 & 125 & 150 & 175\end{array}$

Number of colonies

Fig. 1. Number of ant colonies of different species.

sanguinea ants were identified in the field. Other species were determined in the laboratory.

We also tried to find a connection between stump structure and the presence of ant colonies. We measured the diameter of 77 randomly selected stumps at one of the study sites. In the case of irregular shape of stump surface, we measured maximum width. The preference for tree species and co-occurrence of ant species in the same stump were determined by use of $\chi^{2}$ test. For analysis of ant communities in clearcuts we also used rarefaction curves implemented in Estimate $\mathrm{S}$ 7.5.1. application (Colwell 2005). Statistical analyses were preformed by use of SPSS 13.0 software.

\section{Results}

\subsection{General description of myrmecofauna}

Among 515 controlled stumps, 209 (40.6\%) were used as a nest site by 9 species of ants. An estimate of the total abundance of myrmecofauna on stumps in clearcuts corrected for unseen species Chao 2 (see Colwell 2005 for details) calculated from the whole sample of 515 stumps, was equal to 13.5 species (95\% confidence interval: 9.49 49.92). L. platythorax was the dominant of the community. T. caespitum and F. fusca were less numerous. We also found 10 nests of Leptothorax crassispinus. Other species were found only occasionally (Fig. 1).

Proportion of stumps inhabited by ants varied among clearcuts. Both on 0.5 and 1.5-year-old clearcuts, the frequency of ant colonies in controlled stumps was low. On older clearcuts (2-7 yrs) higher frequencies were observed with the exception of 3.5-year old clearcuts. Ants inhabited a low proportion of stumps on the oldest clearcut as well (Fig. 2).

\subsection{Interactions between ants and the environment}

We found that stumps inhabited by ants were significantly bigger in diameter than ant-free ones (Table 1). The size of stumps colonized by $L$. platythorax was not different from stumps without colonies of this species, but all other species pooled together inhabited significantly larger stumps (Table 1).

All species of ants pooled together as well as L. platythorax inhabited pine and oak stumps in similar proportions. In the case of species other than L. platythorax, they occurred more frequently in oak stumps. This preference, however, was significant only for $F$. fusca and on the verge of significance for T. caespitum (Table 2).

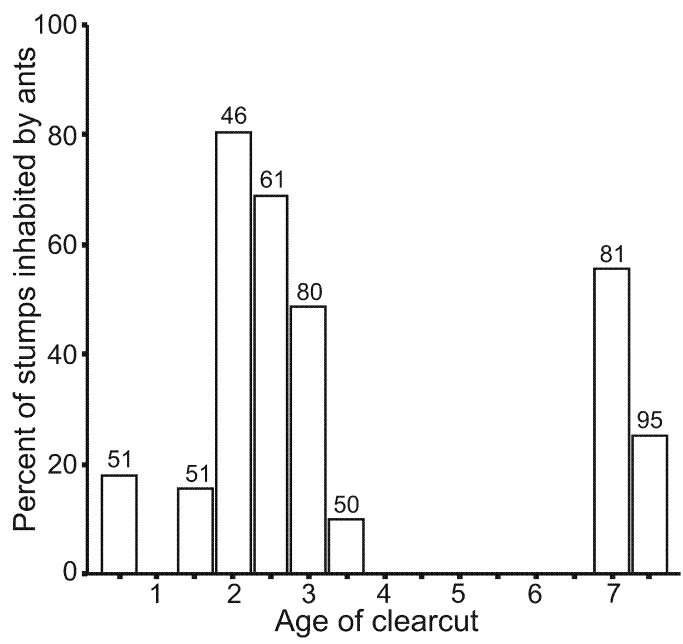

Fig. 2. Proportion of stumps inhabited by ants on different aged clearcuts. Total number of stumps in each category is given above the bars. 
Table 1. Average diameter (in $\mathrm{cm}$ ) of stumps $\pm \mathrm{SD}$ (number of stumps in parentheses) in each category inhabited by ants and ant-free. Mann-Whitney test was applied. L. p. = Lasius platythorax, F. f. = Formica fusca.

\begin{tabular}{|c|c|c|c|c|}
\hline \multirow[b]{2}{*}{ Species } & \multicolumn{2}{|c|}{ Average diameter when ants are } & \multirow[b]{2}{*}{$z$} & \multirow[b]{2}{*}{$p$} \\
\hline & Absent & Present & & \\
\hline All ants together & $35.3 \pm 10.63(57)$ & $42.6 \pm 10.94(20)$ & 2.60 & 0.009 \\
\hline All other than L. $p$. & $36.1 \pm 10.88$ & $42.4 \pm 11.04(14)$ & 1.96 & 0.050 \\
\hline All other than L. p. and $F . f$. & $36.0 \pm 10.77(65)$ & $44.1 \pm 10.84(12)$ & 2.35 & 0.019 \\
\hline Lasius platythorax & $36.7 \pm 11.00(71)$ & $43.2 \pm 11.72(6)$ & 1.44 & 0.151 \\
\hline Formica fusca & $37.4 \pm 11.12(75)$ & $32.5 \pm 7.78(2)$ & 0.61 & 0.543 \\
\hline Tetramorium caespitum & $36.4 \pm 10.97(67)$ & $42.5 \pm 11.23(10)$ & 1.62 & 0.106 \\
\hline
\end{tabular}

The diversity of the ant community inhabiting oak stumps was slightly smaller than that of pine stumps (Fig. 3) but the difference was not significant (i.e. 95\% confidence intervals for Mao Tau estimators overlapped; see Colwell 2005).

\subsection{Interspecific interactions}

We hardly recorded two ant colonies of different species on the same stump. For all species and combinations of species we observed a strong avoidance. We did not find avoidance, however, between $F$. fusca and other species, with the exception of $F$. fusca versus L. platythorax (Table $3)$.

Among all controlled stumps only five were inhabited by more than one ant species. We recorded three cases of co-occurrence of $F$. fusca and $T$. caespitum, one of $F$. fusca and $M$. ruginodis and one of $F$. fusca and $L$. platythorax. Co- occurrence of $F$. fusca with other species was observed more frequently in oak stumps ( 4 cases of co-occurrence per 7 oak stumps inhabited by $F$. fusca) than in pine stumps ( 1 case per 10 pine stumps inhabited by $F$. fusca $)\left(\chi^{2}=8.51, d f=1, p\right.$ $=0.004$; continuity correction).

We did not find any effect of the presence of red wood ants surrounding a stump on ant colonies $\left(\chi^{2}\right.$ test, all cases $\left.d f=1, p>0.212\right)$.

\section{Discussion}

\subsection{General characteristics of the ant community}

In general, we recorded 9 ant species inhabiting stumps. This is similar to the results obtained by Czechowski et al. (1995) who investigated ant communities in fresh coniferous habitats. They recorded 12, 10 and 8 ant species on 3 studied

Table 2. Ant occurrence on pine and oak stumps. Number of occupied stumps in each category are given in parentheses. L. p.: Lasius platythorax, F. f: Formica fusca.

\begin{tabular}{|c|c|c|c|c|}
\hline \multirow[t]{2}{*}{ Species } & \multicolumn{2}{|c|}{$\%$ of stumps inhabited by ants } & \multirow[b]{2}{*}{$\chi^{2}$} & \multirow[b]{2}{*}{$p$} \\
\hline & Pines & Oaks & & \\
\hline All ants together & $41.2(172)$ & $37.8(37)$ & 0.40 & 0.526 \\
\hline All other than Lasius platythorax & $7.7(32)$ & $12.2(12)$ & 2.12 & 0.145 \\
\hline All other than L. p. and F. f. & $5.3(22)$ & $9.2(9)$ & 2.14 & 0.143 \\
\hline Lasius platythorax & $33.8(141)$ & $25.5(25)$ & 2.50 & 0.114 \\
\hline Formica fusca & $2.4(10)$ & $7.1(7)$ & $4.21^{*}$ & 0.040 \\
\hline Tetramorium caespitum & $3.6(15)$ & $8.2(8)$ & $2.88^{*}$ & 0.090 \\
\hline
\end{tabular}

${ }^{*}$ Continuity correction applied. 
Table 3. Interactions between ant species living in stumps. Data from oak and pine stumps are pooled together. Number of stumps settled by given species (and group of species) or by both species together are given in parentheses.

\begin{tabular}{llclcc}
\hline Species 1 & Species 2 & Both species & Interaction & $\chi^{2}$ & $p$ \\
\hline L. platythorax (166) & Remaining (44) & $(1)$ & avoidance & 19.77 & $<0.001$ \\
L. platythorax (166) & $\begin{array}{l}\text { Remaining other } \\
\text { than F. fusca (31) }\end{array}$ & $(0)$ & avoidance & 15.69 & $<0.001$ \\
L. platythorax (166) & T. caespitum (23) & $(0)$ & avoidance & 11.45 & 0.001 \\
L. platythorax (166) & F. fusca (17) & $(1)$ & avoidance & 5.59 & 0.018 \\
F. fusca (17) & T. caespitum (23) & $(3)$ & preferring & $4.32^{*}$ & 0.038 \\
F. fusca (17) & $\begin{array}{l}\text { Remaining other } \\
\text { than L. platythorax (31) }\end{array}$ & $(4)$ & preferring & $6.60^{*}$ & 0.010 \\
& & & & \\
\hline
\end{tabular}

* Continuity correction applied.

plots respectively, however they explored all available microhabitats. Values of the total species richness estimator Chao 2 suggest that in spite of large number of sampled stumps $(>500)$ we still did not record all species inhabiting stumps.

The composition of ant species recorded in stumps in this study, differs from the community detected in all microhabitats available on clearcuts (Mazur 1983, Punttila et al. 1991, Czechowski et al. 1995, Czechowski \& Czechowska 2006). Most probably, the discrepancy results from different preferences for stumps shown by different ant species. For example, high proportion of stumps inhabited by Lasius platythorax may have been driven by a strong preference of that species to nest in dead wood (see also Czechowski et al. 2005). In contrast, relatively low occurrence of Myrmica ruginodis may sug-

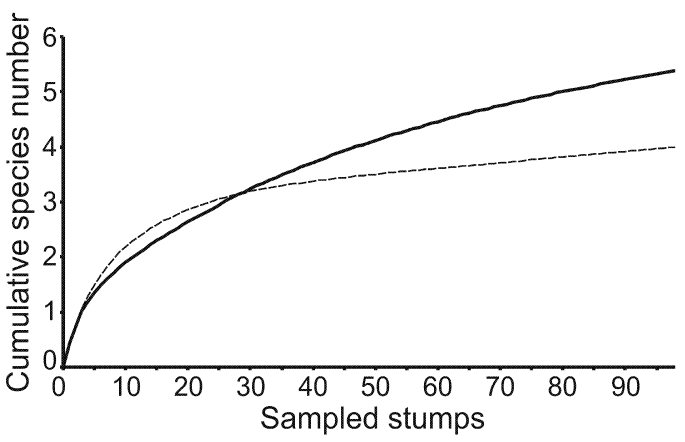

Fig. 3. The expected cumulative number of ant species for a given number of pine (upper, solid line) and oak (lower, broken line) stumps sampled. gest that its preference to nest in stumps is relatively low and/or this species is competitively weaker than other species inhabiting stumps (Pisarski \& Vepsäläinen 1989).

Most species recorded on clearcuts, with the exception of eurytypic Tetramorium caespitum and Formica fusca, are known as forest dwelling ants. This is the general pattern since many forest dwelling ants (but not dominant red wood ants) were reported to increase in number after clearcutting (Puntilla et al. 1991, Czechowski et al. 1995, Czechowski \& Czechowska 2006). This may be the result of an increase in the prey of the ants. Diptera (Szujecki et al. 1983) which are important prey for Myrmica species (Kajak et al. 1972) may be such an example (Szujecki et al. 1983). Moreover, the abundance of red wood ant species is lower on clearcuts as compared to mature stands (authors' unpublished data) probably due to loss of aphid-bearing trees (Punttila et al. 1991). Sources of honeydew from aphids remaining on grass and samplings are likely to be sufficient only for species with colonies less numerous than these of red wood ants. The increase in number of subordinated species may be explained by competitor/predator release.

Research conducted in successive stages on sand dunes in southern Finland (Czechowski et al. 2005) and in coniferous forest in Poland (Czechowski \& Czechowska 2006) leads to the conclusion that $L$. platythorax may play the role of pioneer species. But most probably not all colonies observed by us were established during the colonization period. The occurrence of L. platythorax on the youngest clearcut (0.5-year-old) 
suggests that some colonies were present here in the mature stand (before cutting) and persisted till now. This hypothesis is supported by the occurrence of numerous offspring in some of the ant colonies inhabiting stumps on the youngest clearcut which indicates that these colonies are older than 0.5 year. We suspect that some part of the colonies of $L$. platythorax moved to the nearest stumps from soil nests after clearcutting.

Irrespective of the origin of ant colonies occurring on clearcuts, the percentage of stumps inhabited by L. platythorax should be considered as high. It was confirmed that this species prefers rotten wood both in forest and open habitats (Czechowski et al. 2005). Clearcutting the forest may cause an increase in the amount of dead wood (stumps) volume. This in turn, affects positively the colonisation of the clearcuts by the $L$. platythorax. This presumption is confirmed by the formerly recorded positive effect of stumps left on clearcuts on the abundance of L. platythorax (Czechowski et al. 1995, Czechowski et al. 2005, Czechowski \& Czechowska 2006). On the other hand, floor vegetation cover on clearcuts is sparse, fragmented, and strongly devastated by timber harvesting. This should dramatically decrease the densities of aphids. Therefore trophic conditions for the aphid-related ant community seems to be much worse, compared to that in old-growth forest. It is possible that the trophic ecology of $L$. platythorax inhabiting clearcuts is based mainly on detritus chains strictly related to dead wood resources. This may explain the strong preference of this species for inhabiting dead wood.

The proportion of stumps inhabited by the ants varied among clearcuts. In general, the proportion of inhabited stumps on two youngest clearcuts was low. This may be due to the beginning of the colonisation processes. Also wood hardness and lack of wood destruction caused by saproxylic beetles may also worse stump-availability for ants on the youngest clearcuts. The low frequency of ant colonies on 3.5-year-old clearcut resulted probably from the unfavourable clearcut features, especially the steep slope of the terrain. This steep slope in turn modified insolation and soil moisture.

\subsection{Habitat-ant interaction}

Stump diameter correlated positively with occurrence of some ant species. This may result from the expected correlation of a given stump diameter and probability of its colonisation by the queen which moves in a random direction. This assumption is in accordance with the general pattern of the colonisation of patches in a fragmented landscape (McArthur \& Wilson 1967). Probability of persistence of a given colony may also be related to stump size. Microclimate, for example, temperature and moisture, may be more stable in large stumps which also can offer better protection against predators (such as woodpeckers using stumps on clearcuts to forage; Rolstad \& Rolstad 2000). This is especially true in the case of large stumps. Therefore, stump size may be important for an ant colony's growth and persistence. This may suggest that modification of the threshold age used by foresters for classification of a given forest patch for harvesting may indirectly affects ant community. It may also affect interspecific interactions on clearcuts.

\subsection{Interspecific interactions}

We recorded strong interspecific avoidance among particular ant species with the exception of F. fusca. F. fusca often co-occurred with other species (Table 3). Interspecific avoidance is expected due to strong antagonistic interactions (based on competition and predation) between particular species (Pisarski \& Vepsäläinen 1989, Gallé 1990, Punttila et al. 1996). For example, it was proved that the distribution of the superior ant species belonging to the red wood ant group, shapes the distribution of other, competitively weaker ants. It also shapes the distribution of many other epigeic invertebrates (Hawes et al. 2002, Reznikova \& Dorosheva 2004). F. fusca, as a non-aggressive species accidentally may occur in the vicinity of other ants on the basis of plesiobiosis. However, we recorded that $F$. fusca co-occurred with other species more frequently than expected by random (Table 3 ). Perhaps, vicinity of other ants, especially $T$. caespitum, gives protection against the common $L$. platythorax. The differences in the ecology of the two species 
(F. fusca and T. caespitum) are large enough to enable their co-occurrence and plesiobiosis (Czechowski 2004).

Co-occurrence of two species was observed mainly on oaks. There is no clear explanation for this. All the cases of two species co-occurrence were related to $F$. fusca, which preferred oaks (Table 3). However, F. fusca co-occurred with other species significantly more often on oaks than on pines. Therefore, inhabiting of one oak stump by two species did not result from $F$. fusca preference for oaks. Note, that F. fusca co-occurred with other species in 4 out of 7 stumps, in spite of the fact that 61 remaining oak stumps were not inhabited by any ant species. This question must be investigated in further research.

We did not record any effect of the presence of red wood ants on the floor of clearcuts on stump colonisation. Red wood ants significantly affect distribution and abundance of other ant species, other invertebrates or even vertebrates, (Aho et al. 1997, Haemig 1999, Hawes et al. 2002, Reznikova \& Dorosheva 2004, Jäntti et al. 2007). It is possible that the stump may effectively protect the colony inhabiting it. This is especially true if the workers which belong to the colony forage inside the stump. However, the lack of the effect of red wood ants on the percentage of stumps inhabited, may be caused by the fact that we recorded only the present distribution of nests in stumps. The response of the distribution of colonies to the occurrence of other ants may be, however, time-lagged (Gallé 1990).

Acknowledgements. We thank Prof. Jan R. E. Taylor for improving the English and an anonymous referee for helpful comments on the manuscript.

\section{References}

Aho, T., Kuitunen, M., Suhonen, J., Jantti, A. \& Hakkari, T. 1997: Behavioural responses of Eurasian treecreepers, Certhia familiaris, to competition with ants. Animal Behaviour 54: 1283-1290.

Colwell, R. K. 2005: Estimates: Statistical estimation of species richness and shared aspecies from samples. Version 7.5. User's Guide and application published at: URL http://purl.oclc.org/estimate (access date: September 2008).

Czechowski, W. 2004: Scarcity of sites suitable for nesting promotes plesiobiosis in ants (Hymenoptera: Formicidae). - Entomologica Fennica 15: 211-218.
Czechowski, W. \& Czechowska, W. 2006: Succession of Lasius s. str. species (Hymenoptera: Formicidae) in moist pine forests - reassesement after taxonomic revisions of the subgenus. - Fragmenta Faunistica 49 (2): 91-97.

Czechowski, W., Czechowska, W. \& Vepsäläinen, K. 2005: Structure and succession of Lasius s. str. (Hymenoptera: Formicidae) assemblages in a Finnish sand dune area - reassessment after taxonomic revisions of the subgenus. - Entomologica Fennica 16: 2-8.

Czechowski, W., Pisarski, B. \& Yamauchi, K. 1995: Succession of ant communities (Hymenoptera, Formicidae) in moist pine forests. - Fragmenta Faunistica 38: 447-486.

Falarz, M. 2004: Variability and trends in the duration and depth of snow cover in Poland in the 20th century. International Journal of Climatology 24: 1713-1727.

Friedrich, S. 1998: Cedyński Park Krajobrazowy - charakterystyka fizjograficzna i geobotaniczna. - Przegląd Przyrodniczy 9 (3): 3-18.

Gallé, L. 1990: Assembly of sand forest ant communities. - Memorabilia Zoologica 44: 1-6.

Gallé, L. 1991: Structure and succession of ant assemblages in north European sand dune area. - Holaretic Ecology 14: 31-37.

Haemig, P. D. 1999: Predation risk alters interactions among species: competition and facilitation between ants and nesting birds in a boreal forest. — Ecology Letters 2: 178-184.

Hawes, C., Stewart, A. J. A. \& Evans, H. F. 2002: The impact of wood ants (Formica rufa) on the distribution and abundance of ground beetles (Coleoptera: Carabidae) in a Scots pine plantation. - Oecologia 131: $612-619$.

Jäntti, A., Suorsa, P., Hakkarainen, H., Sorvari, J., Huhta, E. \& Kuitunen, M. 2007: Within territory abundance of red wood ants Formica rufa is associated with the body condition of nestlings in the Eurasian treecreeper Certhia familiaris. - Journal of Avian Biology 38: 619624.

Kajak, A., Breymeyer, A., Pętal, J. \& Olechowicz, E. 1972: The influence of ants on the meadow invertebrates. - Ekologia Polska 20 (17): 163-171.

Kondracki, J. 2002: Geografia regionalna Polski. - PWN, Warszawa. 440 pp. [In Polish]

Kujawa-Pawlaczyk, J. \& Pawlaczyk, P. 1999: Operat ochrony ekosystemów leśnych Cedyńskiego Parku Krajobrazowego - on CD. — Wyd. Lubuskiego Klubu Przyrodników, Świebodzin. [In Polish]

MacArthur, R.H. \& Wilson, E.O. 1967: The theory of island biogeography. - Princeton University Press, Princeton. 203 pp.

Mazur, S. 1983: Mrówki borów sosonowych Polski. Rozprawy naukowe i monografie 25. - Wydawnictwo SGGW-AR, Warszawa. 71 pp. [In Polish]

Pisarski, B. \& Vepsäläinen, K. 1989: Competition hierarchies in ant communities (Hymenoptera, Formicidae). - Annales Zoologici 42: 321-328.

Punttila, P., Haila, Y., Pajunen \& Tukia, H. 1991: Coloni- 
sation of clearcut forests by ants in southern Finnish taiga: a quantitative survey. - Oikos 61: 250-262.

Punttila, P., Haila, Y. \& Tukia, H. 1996: Ant communities in taiga clearcuts: habitat effects and species interactions. - Ecography 19: 16-28.

Reznikova, Z. \& Dorosheva, H. 2004: Impacts of red wood ants Formica polyctena on the spatial distribution and behavior patterns of ground beetles (Carabidae). Pedobiologia 48: 15-21.
Rolstad, J. \& Rolstad, E. 2000: Influence of large snow depths on Black Woodpecker Dryocopus martius foraging behavior. - Ornis Fennica 77: 65-70.

Szujecki, A., Szyszko, J., Mazur, S. \& Perliński, S. 1983: The process of forest soil macrofauna formation after afforestation of farmland. - Warsaw Agricultural University Press, Warszawa. 196 pp. 